\title{
Role of obstetrician and gynecologist in diagnosis and management of breast lump
}

\author{
Kavita A. Chandnani*, H. B. Sainee
}

Department of Obstetrics and Gynecology, SBKS Medical Institute \& Research Centre and Dhiraj General Hospital, Piparia, Vadodara, Gujarat, India

Received: 27 April 2013

Accepted: 10 May 2013

\section{*Correspondence:}

Dr. Kavita A. Chandnani,

E-mail: kavyawch@rediffmail.com

(C) 2013 Chandnani KA et al. This is an open-access article distributed under the terms of the Creative Commons Attribution Non-Commercial License, which permits unrestricted non-commercial use, distribution, and reproduction in any medium, provided the original work is properly cited.

\begin{abstract}
Background: This study of last three years undertaken to determine the types of breast lumps as seen by an obstetrician and gynecologist and to determine the high risk factors for diagnosing malignant breast lump and guide patient for early and proper management.

Methods: The diagnostic triad of clinical examination, FNAC and mammography was used to help detect a malignant mass.

Results: Out of 202 cases, 162 were of benign breast lump and 40 of malignant breast lump. Age and family history were the most important risk factors. Other risk factors were nulliparity, first child after 30 years of age and postmenopausal age. Fibroadenoma was the most common benign tumor usually occurring at a younger age. Of the 40cases of malignant breast lump, only $45 \%$ were detected early.

Conclusion: All gynecologist should examine patient's reproductive organs as well breast and also learn patient how to examine breast herself regularly. Thus all obstetrician and gynecologist should participate in the breast cancer screening and help detect this malignancy in its early stage.
\end{abstract}

Keywords: Breast lump, Cancer, Obstetrician and Gynecologist

\section{INTRODUCTION}

As an integral part of the female reproductive system, the breasts are within the purview of obstetrics and gynecology. Furthermore many, if not most, women will consult their obstetrician-gynecologist when they have breast symptoms or concerns. Also, most women have questions about breast cancer, mammography, and hormone therapy - either combined estrogen/ progesterone or estrogen alone. Finally, a thorough breast examination is an essential component of a general physical or annual examination. Therefore, obstetrician-gynecologists should be able to diagnose and manage benign breast problems and make appropriate referrals when indicated. They should recommend, in addition, that all women aged 40 and older have annual screening mammography. ${ }^{4}$
It is important to bear in mind that most patients who present with a breast complaint do not have a malignancy, but, once a patient presents with a problem, regardless of her age, a physician must treat the complaint seriously and pursue all available methods to make a proper diagnosis. ${ }^{6}$ In India breast cancer is the second common malignancy after cervical cancer and is detected in 20 per 1,00,000 women. The incidence is increasing in most countries at the rate of one to two percent annually and soon nearly one million women will develop this disease every year throughout the world. ${ }^{1}$ Hence, the obstetrician and gynecologist should be fully educated in the diagnosis and treatment of disease of the breast and should participate in screening programmes and preventive strategies for breast cancer. 


\section{Aims and Objectives}

The main aim of the study was to determine the most common types of breast lumps presenting to an obstetrician and gynecologist and to decide which breast lumps are more likely to be malignant.

\section{METHODS}

Present study was conducted in the department of Gynecology and Obstetrics, Dhiraj Hospital, S.B.K.S. MIRC, Piparia, Vadodara, Gujarat from February 2010 to January 2013.

All cases of breast lumps which presented first to the obstetrician and gynecologist were studied to determine their clinical features, mammography study and final histopathological diagnosis from FNAC.

\section{Clinical Breast Examination}

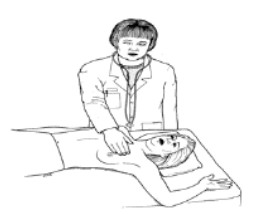

Proper position for palpation of the breast with the patient comfortably supine (Hindle WH: Breast Care, p 45, New York, Springer-Verlag, 1999; with permission).

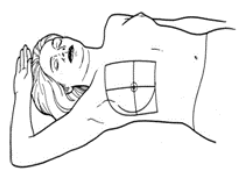

Outline of the breast and surrounding area to be palpated systematically (Hindle WH: Breast Care, p 45. New York, Springer-Verlag, 1999; with permission).

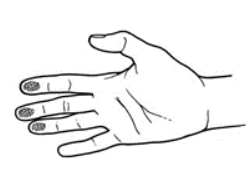

Pads of the second, third, and fourth fingers are the most sensitive for breast palpation (Hindle WH: Breast Care, p 45. New York, SpringerVerlag, 1999; with permission).

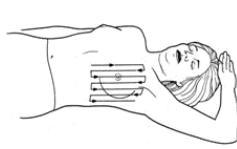

A vertical strip pattern is most effective for systematic palpation of the breast (Hindle WH: Breast Care, $\mathrm{p}$ 46. New York, Springer-Verlag, 1999; with permission)

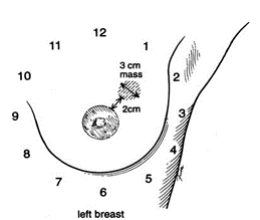

Precise location and measured size of a mass can be effectively described using the clock position. The mass in this illustration should be recorded as: left breast, dominant $3-\mathrm{cm}$ mass at 1 o'clock position, $2 \mathrm{~cm}$ from the areolar border (Hindle WH: Breast Care, p 50. New York, Springer-Verlag, 1999; with permission).

\section{Screening and Diagnostic Breast Imaging}

The BI-RADS descriptive patterns of mammographic breast density.

- The breast is almost entirely fat.
- There are scattered fibroglandular densities that could obscure a lesion on mammography.

- $\quad$ The breast tissue is heterogeneously dense; this may lower the sensitivity of mammography.

- The breast tissue is extremely dense, which lowers the sensitivity of mammography.

The BI-RADS mammographic assessment categories:

\begin{tabular}{|ll|}
\hline Category 0 & Need additional imaging evaluation \\
\hline Category 1 & Negative \\
\hline Category 2 & Benign finding \\
\hline Category 3 & $\begin{array}{l}\text { Probably benign finding: short interval } \\
\text { follow-up suggested }\end{array}$ \\
\hline Category 4 & $\begin{array}{l}\text { Suspicious abnormality: biopsy should } \\
\text { be considered }\end{array}$ \\
\hline Category 5 & $\begin{array}{l}\text { Highly suggestive of malignancy: } \\
\text { appropriate action should be taken }\end{array}$ \\
\hline
\end{tabular}

\section{Fine-Needle Aspiration: Techniques, Cytology, and Pathology}

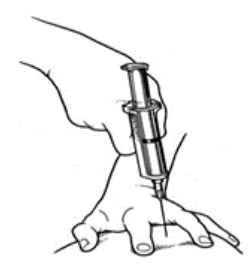

Fine-needle aspiration with a syringe holder and a 10-milliliter disposable syringe (Hindle WH: Breast Care, $\mathrm{p}$ 95. New York, Springer-Verlag, 1999; with permission).

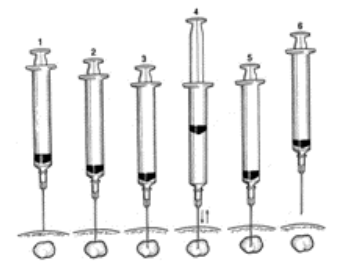

Sequential steps (1 through 6) of the traditional fine-needle aspiration technique using suction by negative pressure created by drawing back on the barrel of the syringe when (and only when) the needle tip is in the mass to be aspirated (Hindle WH: Breast Care, p 102. New York, Springer-Verlag, 1999; with permission).

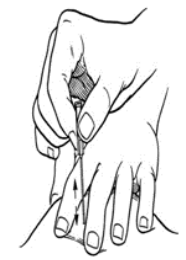

Fine-needle-alone sampling with 30 perpendicular sharp thrusts of the needle tip with the mass (drawn by Peggy Firth) (Hindle WH: FNA in office practice. Clin Obstet Gynecol 45:762, 2002, with permission).

\section{RESULTS}

Two hundred and two cases of breast lumps were seen between Feb 2010 to Jan 2013. From 202 cases, 162 were benign and 40 were malignant.

$67.9 \%(110 / 162)$ patients with benign lump were less than 25 years of age while $85 \%$ (32/40) with malignant 
disease were more than 40 years of age. 32/40 and $105 / 162$ patients from the malignant and benign group respectively were married (Table 1). Thirty percent in the malignant group were nulliparous and $40 \%$ had not breast fed their child. 60/162 in benign group were nulliparous and 69/162 had not breast fed their child. While $70 \%$ patients in the malignant group were postmenopausal, only $6.7 \%$ patients in the benign group were postmenopausal. Family history of malignant was positive in $27.5 \%$ patients in the malignant group and $14 \%$ in the benign group.

Table 1: Clinical features of patients with breast lump.

\begin{tabular}{|c|c|c|}
\hline Clinical features & Malignant & Benign \\
\hline \multicolumn{3}{|l|}{ Age } \\
\hline $18-25$ & & 110 \\
\hline $26-40$ & 08 & 41 \\
\hline $41-65$ & 32 & 11 \\
\hline \multicolumn{3}{|l|}{ Marital status } \\
\hline Unmarried & 08 & 57 \\
\hline Married & 32 & 105 \\
\hline \multicolumn{3}{|l|}{ Parity } \\
\hline Nulliparity & 12 & 60 \\
\hline $\begin{array}{l}\text { First Child after } 30 \\
\text { years of age }\end{array}$ & 08 & 28 \\
\hline \multicolumn{3}{|l|}{ Breast feeding } \\
\hline $\begin{array}{l}\text { Breast Feeding less } \\
\text { than } 10 \text { months }\end{array}$ & 16 & 69 \\
\hline More than 10 months & 24 & 93 \\
\hline \multicolumn{3}{|l|}{ Family history } \\
\hline Breast Cancer & 04 & 06 \\
\hline Any other cancer & 07 & 20 \\
\hline $\begin{array}{l}\text { Hormone Replacement } \\
\text { Therapy }\end{array}$ & 02 & 02 \\
\hline
\end{tabular}

Lump in breast was the most common presenting symptom in both groups (Table 2). Pain was associated complaint in 16/40 malignant cases and 120/162 benign cases. Nipple discharge was the presenting complaint in 22/202 cases of which six were diagnosed to be malignant and 16 benign. Fibroadenoma was the most common benign lump viz $84.5 \%$ (137/162). Giant fibroadenoma, intraductal papilloma, nipple adenoma, chronic abscess, lipoma, galactocele, tuberculosis and antibioma were the other benign lumps (Table 3). Out of the 40 malignant cases, only 18 or $45 \%$ cases were detected early. Rest of the patients had advanced malignancy with two having spinal metastasis, four having secondaries in the liver, one having had cerebral metastasis and one having malignant pleural effusion.
Table 2: Presenting complaints in patients with breast lump.

\begin{tabular}{|lll|}
\hline & Malignant & Benign \\
\hline Lump in breast & 22 & 140 \\
\hline Pain & 16 & 120 \\
\hline Irregular size & 02 & 08 \\
\hline Low grade fever & 12 & 04 \\
\hline $\begin{array}{l}\text { Nipple } \\
\text { discharge }\end{array}$ & 06 & 16 \\
\hline Dry cough & 04 & 02 \\
\hline $\begin{array}{l}\text { Severe } \\
\text { Backache }\end{array}$ & 02 & Nil \\
\hline
\end{tabular}

Table 3: Final histopathological diagnosis of breast lump.

\begin{tabular}{|ll|}
\hline Histopathology / Staging & No. \\
\hline Benign & \\
\hline Fibroadenoma & 137 \\
\hline Giant fibroadenoma & 02 \\
\hline Intraductal papilloma & 04 \\
\hline Nipple adenoma & 02 \\
\hline Chronic abscess & 04 \\
\hline Lipoma & 02 \\
\hline Galactocele & 03 \\
\hline Tuberculous mastitis & 03 \\
\hline Antibioma & 05 \\
\hline Malignant ( Adenocarcinoma) & \\
\hline I & 18 \\
\hline II & 02 \\
\hline III & 14 \\
\hline IV & 06 \\
\hline
\end{tabular}

\section{DISCUSSION}

The two strongest risk factors for breast cancer are age and family history of breast cancer. The other risk factors like late age at first childbirth, nulliparity, diet, obesity, breast feeding, alcohol and hormones account for only 20-29 percent of breast cancers. $^{8}$ 
Breast cancer increases in frequency with increasing age. One in nine women aged 85 will develop cancer as against one in fifty aged 50 years. ${ }^{8}$ In the present study (32/40) $80 \%$ patients with malignant disease were more than 40 years old. Thus women between $40-65$ years of age will benefit maximally from screening.

Five to ten percent of breast cancers are inherited and affect multiple members in many generations. The relative risk is 1.5 to 2 with first degree relatives. ${ }^{9}$ In the present study the family history of breast cancer was more in the malignant group $(27.5 \%)$ as compared to the benign group (12.8\%). This difference was not statistically significant.

Thirty percent in the malignant group were nulliparous and $20 \%$ had their first child after 30 years of age. Nulliparity and late age at first childbirth, both increase the life time incidence of breast cancer. ${ }^{10}$ The risk of cancer in women who had their first child after 30 years of age.

Lactation offers a weak to moderate protective effect only for premenopausal breast cancer but there was no reduction in the risk of breast cancer in postmenopausal women who had lactated ${ }^{7}$. In the present study, $40 \%$ patients had breast fed their children for more than 10 months in every pregnancy.

Seventy percent patients in the malignant group were postmenopausal indicating a higher incidence of malignant disease in the postmenopausal women. The number of patients on hormone replacement therapy were too less to draw any conclusions.

Lump in the breast and pain were the most common presenting symptoms in both groups. Evaluation of a breast lump was done by the diagnostic triad of physical examination, imaging and tissue sampling by FNAC or core biopsy. ${ }^{3}$ Mammography was done because it not only gives an impression of the palpable lump, but it also helps in the evaluation of the remaining breast tissue for presence of nonpalpable lesions. ${ }^{4}$ Mammography is not done in younger women because of low incidence of carcinoma in them and the technical difficulties in evaluating their dense breast tissue. ${ }^{3}$

Nipple discharges commonly associated with a malignant lesion are usually clear or watery, yellow or serous, pink or serosanguineious and bloody or sanguineous. In the present study, nipple discharge was the presenting complaint in $10.4 \%$ of the patients of which six were diagnosed to have malignant lump while 16 had a benign lump.
Fibroadenoma were the most common benign tumours $(84.3 \%)$. Clinically they are painless, well circumscribed, freely mobile with a rounded, lobulated or discoid configuration. ${ }^{5}$ In Indian literature the reported incidence varies from 40 to $87 \%$ of breast biopsies. ${ }^{2}$ The other benign tumors were giant fibroadenoma, intraductal papilloma, nipple adenoma, chronic abscess, lipoma, galactocele, tuberculosis and antibiomas.

The prototypical common adenocarcinoma of the breast presents in a women as a solitary, painless, nontender, immobile, firm to hard and ill defined mass. There may be in drawing of nipple. In the present study, out of the 40 diagnosis increases the mortality. Hence it becomes mandatory for an obstetrician and gynecologist to understand and participate actively in the breast cancer screening.

\section{REFERENCES}

1. Beahrs OH, Henson DE, Hutter RVP, et al. American Joint Committee on cancer. Manual for staging of Breast Cancer, $3^{\text {rd }}$ ed. Philadelphia. J B Lippincott 1997;145-50.

2. Cole P, Elwood JM, Kaplan SD. Incidence rates and risk factors of benign breast diseases. Am J Epidemiology 1978;108:112-20.

3. Hermansen C, Paulson HS, Jenson I, et al. Diagnostic reliability of combined physical examination, mammography and FNAC in breast tumors. A prospective study. Cancer 1978;60:186671.

4. Hindle WH. The diagnosis and management of benign Breast diseases. Glob Lib Women's Med 2009;499-517.

5. Isaacs JH. Benign tumors of the Breast. Obstet Gynecol Clinics of North America 1994;21:487-97.

6. Lannin DR, Harris RP, Swanson FH, et el. Difficulties in diagnosis of carcinoma of the breast in patients less than 50 years of age. Surg Gynecol Obstet 1993; 177:457-60.

7. Newcomb PA, Storr BE, Loongnecker MP, et al. Lactation and a reduced risk of postmenopausal breast cancer. N Engl J Med 1994;330:81-7.

8. Nichols DH. The epidemiologic characteristics and Breast Cancer. Clin Obstet Gynecol 1994;37:92532.

9. Ottman R, Pike MC, King Mc, et al. Practical guide for estimating risk for familial breast cancer. Lancet 1983;2:556-8

10. White E. Projected changes in breast cancer incidence due to the trend of delay in childbearing. Am J Public Health 1987;77:495-7.

DOI: $10.5455 / 2320-1770 . i j r \operatorname{cog} 20130906$

Cite this article as: Chandnani KA, Sainee HB.

Role of obstetrician and gynecologist in diagnosis and management of breast lump. Int J Reprod Contracept Obstet Gynecol 2013;2:288-91. 